\title{
Macroeconomic Shocks In The Cypriot Economy And The Emu-Area Countries
}

Dimitrios Tsoukalas, (Email:tsoukala@ calumet.purdue.edu), Purdue University- Calumet

\begin{abstract}
This study analyzes macroeconomic shocks in Cyprus and the EMU-area from the beginning of 1990 to the end of 2004. We examine the relative importance of aggregate demand and supply shocks along with money, in explaining short-run real output fluctuations. The empirical results for the analysis are obtained by using the framework of structural vector autoregression model (SVAR). The structural impulses in the VAR model are defined as shocks in aggregate demand, aggregate supply and money growth. Results indicate that shocks in AD, AS, the money growth are all sources of macro shocks in Cyprus and the EMU-area.
\end{abstract}

\section{INTRODUCTION}

$T$

he sources of macroeconomic fluctuations or business cycles have been the topic of many macroeconomic studies $_{1}$ and the focus of many debates among various schools of economics. Macroeconomic theories have quite different opinions about the properties of the aggregate supply and aggregate demand curves in the short-run and the long-run, and thus these theories predict different impacts of monetary and other demand shocks on the business cycle fluctuations; The more controversial issue is probably the real effects of nominal money (see for example the Classical and New-Classical along with Keynesian and New-Keynesian views).

The empirical findings of studies using the VAR approach are mixed: some support one theory while others support other theories. Sims (1980b) showed that adding a short-term nominal interest rate into a VAR model of the industrial production, money (M1), and wholesale prices, leads to the elimination of the originally high predictive power of money for output. Sims explains this as a Real Business Cycle phenomenon in which changes in the stock of money reflect people's expectations about future output (Bernanke 1986). Blachard (1989) supports the Keynesian view of the effects of money on output, analyzing U.S. data. Gali (1992) uses the IS-LM model to explain the postwar data for the behavior of money, interest rates, price and output. Karras (1993) summarizes the consensus in the following propositions: 1) aggregate supply disturbances have permanent effects on output, 2) aggregate demand disturbances have mainly temporary effects on output, 3) aggregate demand and supply affect inflation in the short-run, and 4) inflation is a monetary phenomenon in the long-run.

Studies in other emerging markets have shown similar results as the above studies. Hanying Yu (1994), in a multi-country study using a VAR shows that in Japan, South Korea and Australia AD, AS and Money supply shocks are important in explaining output and price fluctuations.

Several studies have used the Structural Vector Autoregressive models, to analyze the transmission mechanism of fiscal and monetary policy along with AD-AS fluctuations within the EMU-area. Garcia and Verdelham (1999), study the fiscal and monetary policy transmission mechanism by identifying aggregate demand-supply shocks, nominal shocks, fiscal and monetary policy shocks in the aggregate Euro-area economy. Dalsgaard and de Serres (2000) used a four variable SVAR model with real output growth, inflation, change of private sector savings, and the ratio of government net lending to GDP in 11 European countries. 
In this study we use the Structural Vector Autoregressive method (SVAR) and discuss the sources of macroeconomic fluctuations (the business cycle) in the Cypriot economy. We will focus on the relative importance of aggregate demand, aggregate supply and monetary shocks in determining real output. The advantages of the Structural VAR approach is that it provides useful statistical tools (e.g. Granger causality, impulse response functions and variance decompositions, etc.) to test the hypotheses of the business cycle.

\section{METHODOLOGY, DATA ANALYSIS, VARIABLES IN THE SYSTEM AND HYPOTHESES TO BE INVESTIGATED}

The method used here (the structural Vector Autoregression (VAR) approach) is a modification of the "atheoritical" VAR approach developed by Sims (1980). The main advantage of study the dynamic responses of a system to a shock. Analysis of the pattern of innovations and responses in stock markets can be precisely performed by the impulse response function analysis in the VAR model.

For the analysis we construct a basic three-variable model where the variables are real output, price level and the money supply; extended four-variable models where the variables are real output, price level, money supply and the exchange rate, to analyze the aggregate demand and aggregate supply shocks in Cyprus. The variables of interest are output $Y$, and the price level P. These variables are assumed to be driven by shocks in aggregate demand, aggregate supply and the money supply or $\left(\mathrm{u}^{\mathrm{d}}, \mathrm{us}^{\mathrm{s}}\right.$, and $\left.\mathrm{u}^{\mathrm{m}}\right)$. Shocks in aggregate demand come mainly from unexpected changes in output, shocks in aggregate supply come from unexpected changes in the price level, and shocks in the money supply come from unexpected changes in the supply of money.

The assumption that will be used to achieve identification of this type of disturbance is that unexpected news about $\mathrm{AD}$ (such as changes in taxes, consumption etc) only have temporary effects on real output. An increase in $\mathrm{AD}$ for example, may initially cause real output to deviate from their long-run permanent value or mean. In the long-run however, real output will return to its long-run value. We assume that in the long-run surprises in AD have no persistent effects on real output. This assumption agrees with new-classical and theories that in that only unanticipated changes AD.

Assume that the structural model is:

$\mathrm{X}_{\mathrm{t}}=\sum_{\mathrm{i}=1}^{\mathrm{n}} \mathrm{A}_{\mathrm{i}} \mathrm{X}_{\mathrm{t}-\mathrm{i}}+\mathrm{u}_{\mathrm{t}}$

where $\mathrm{X}=(\mathrm{Y}, \mathrm{P}, \mathrm{M})$ ': the vector of variables used in the model, $\mathrm{Y}=$ real output, $\mathrm{P}=$ the price level, $\mathrm{M}=$ the money supply, $\mathrm{u}=\left(\mathrm{u}_{\mathrm{y}}, \mathrm{u}_{\mathrm{s}}, \mathrm{u}_{\mathrm{m}}\right)$ are serially and cross-equation uncorrelated.

From (1) we get the reduced form: $\mathrm{X}_{\mathrm{t}}=\sum_{\mathrm{i}=1}^{\mathrm{n}} \mathrm{G}_{\mathrm{i}} \mathrm{X}_{\mathrm{t}-\mathrm{i}}+\mathrm{e}_{\mathrm{t}}$ the VAR analysis is that it is suited to (2) an illustration of a two variable model is:

$\mathrm{Y}_{\mathrm{t}}=\mathrm{d}_{11} \mathrm{Y}_{\mathrm{t}-1}+\mathrm{d}_{12} \mathrm{P}_{\mathrm{t}-1}+\mathrm{d}_{13} \mathrm{M}_{\mathrm{t}-1}+\mathrm{e}_{1 \mathrm{t}}$

(2.a)

$\mathrm{P}_{\mathrm{t}}=\mathrm{d}_{21} \mathrm{Y}_{\mathrm{t}-1}+\mathrm{d}_{22} \mathrm{P}_{\mathrm{t}-1}+\mathrm{d}_{23} \mathrm{M}_{\mathrm{t}-1}+\mathrm{e}_{2 \mathrm{t}}$

$\mathrm{M}_{\mathrm{t}}=\mathrm{d}_{31} \mathrm{Y}_{\mathrm{t}-1}+\mathrm{d}_{32} \mathrm{P}_{\mathrm{t}-1}+\mathrm{d}_{33} \mathrm{M}_{\mathrm{t}-1}+\mathrm{e}_{3 \mathrm{t}}$

(2.c)

Inverting (2) we get:

$\mathrm{X}_{\mathrm{t}}=\Sigma^{\infty}{ }_{\mathrm{s}=0} \mathrm{G}_{\mathrm{s}} \mathrm{X}_{\mathrm{t}-\mathrm{s}}$

(3)

where $\mathrm{X}=(\mathrm{Y}, \mathrm{P}, \mathrm{M})^{\prime}$, and $\mathrm{u}=\left(\mathrm{u}^{\mathrm{y}}, \mathrm{u}^{\mathrm{p}}, \mathrm{u}^{\mathrm{m}}\right)$ are the structural demand, supply and the money shocks respectively that are serially 
$\underline{6}$

uncorrelated and cross-uncorrelated.

In matrix form the model is

(1-L) $\quad \mathrm{Y} \quad \mathrm{G}_{11} \mathrm{G}_{12} \mathrm{G}_{13} \quad \mathrm{u}^{\mathrm{y}}$

$\begin{array}{llllll}P & \mathrm{G}_{21} & \mathrm{G}_{22} & \mathrm{G}_{23} & \mathrm{u}_{\mathrm{p}}\end{array}$

$\begin{array}{lllll}M & G_{31} & G_{31} & G_{33} & u_{m}\end{array}$

For example the output equation is

$\mathrm{Y}_{\mathrm{t}}=\left[\mathrm{G}_{11} /(1-\mathrm{L})\right] \mathrm{u}^{\mathrm{y}}+\left[\mathrm{G}_{12} /(1-\mathrm{L})\right] \mathrm{u}^{\mathrm{s}}+\left[\mathrm{G}_{13} /(1-\mathrm{L})\right] \mathrm{u}^{\mathrm{m}}$

where $V_{i j}=G_{i j} /(1-L)$ is the impulse response function of each input $j$.

If we forecast $\mathrm{Y}_{\mathrm{t}}$ by (3.1), and we write the derivation in $\mathrm{Y}_{\mathrm{t}}$ from the forecast generated at time (t-k-1) as:

$\mathrm{Y}_{\mathrm{t}}-\mathrm{Y}_{\mathrm{t}-\mathrm{k}-\mathrm{l}}=\sum_{\mathrm{i}=0}^{\mathrm{k}} \mathrm{g}_{11, \mathrm{i}} \mathrm{u}_{\mathrm{t}-\mathrm{i}}^{\mathrm{d}}+\sum_{\mathrm{i}=0}^{\mathrm{k}} \mathrm{g}_{12, \mathrm{i}} \mathrm{u}_{\mathrm{st}-\mathrm{i}}+\sum_{\mathrm{i}=0}^{\mathrm{k}} \mathrm{g}_{13, \mathrm{i}} \mathrm{u}_{\mathrm{mt}-\mathrm{i}}$

then the proportion of the variance of real output forecast errors at horizon $\mathrm{k}$ which can be explained by the shocks in aggregate demand shocks will be:

$\mathrm{V}_{\mathrm{i}}(\mathrm{k})=\Sigma^{\mathrm{ki}=0} \mathrm{~g}_{11, \mathrm{i}}^{2} / \Sigma^{\mathrm{ki}=0} \mathrm{~g}_{11, \mathrm{i}}^{2}+\Sigma^{\mathrm{ki}=0} \mathrm{~g}_{12, \mathrm{i}}^{2}+\Sigma^{\mathrm{ki}=0} \mathrm{~g}_{13, \mathrm{i}}^{2}$

The impulse response functions and the variance decompositions are estimated based on equations (3.2) and (3.3).

The database consists of time series of quarterly data for the period 1990: Q1 to 2004: Q4 for GDP, money supply, the consumer price index, and the exchange rate $(\$ /$ lira)t. The data were provided by the IMF statistics.

All variables have been tested for unit roots and cointegration (tests are available upon request). All variables after transformations are stationary. Real variables have been adjusted for the inflation rate. The variables used for the final analysis are: growth rate of real output, RIPG, growth rate of real money supply, RMG, the inflation rate INF, and the exchange rate $\mathrm{XR}$.

Hypotheses to be investigated:

- $\quad$ monetary shocks have a positive effect on $\mathrm{Y}$ and $\mathrm{P}$

- $\quad$ AD shocks have positive effects on Y and P

- $\quad$ negative AS shocks have negative effects on $\mathrm{Y}$ but positive on $\mathrm{P}$

- $\quad$ importance of AD shocks decreases over time

- $\quad$ importance of AS shocks for Y increases over time

- $\quad$ monetary shocks are mostly responsible for $\mathrm{P}$ in the long-run

\section{EMPIRICAL RESULTS}

\section{Reduced form evidence (Granger causality tests)}

VAR models are used to test for causality in the sense of Granger (1969). ${ }^{\mathrm{i}}$ To implement the Granger test in what follows, we estimate the reduced form of VAR equation by equation in an OLS regression of the form: 


\section{$\underline{6}$}

$\mathrm{Z}_{\mathrm{t}}=\Sigma_{\mathrm{i}=1}^{\mathrm{k}} \alpha_{\mathrm{i}} \mathrm{Y}_{\mathrm{t}-\mathrm{i}}+\Sigma_{\mathrm{i}=1}^{\mathrm{k}} \beta_{\mathrm{i}} \mathrm{INF}_{\mathrm{t}-\mathrm{i}}+\Sigma_{\mathrm{i}=1}^{\mathrm{k}} \gamma_{\mathrm{i}} \mathrm{RMG}_{\mathrm{t}-\mathrm{i}}+\mathrm{e}_{\mathrm{t}}$

where $\mathrm{Z}=\mathrm{Y}$, INF or RMG.

where $\mathrm{Y}=$ real output, INF is the inflation rate and RMG is the real growth rate of the money supply. The Granger test regresses real output on lagged real output, lagged inflation and lagged money supply and tests the lags of inflation and the real money supply. ${ }^{\text {ii }}$. The Granger F-statistic, tests the null hypothesis that INF and RMG do not Granger-cause (predict) $\mathrm{Y}$ in equation (2). The null is rejected if the coefficients $\mathrm{a}_{\mathrm{i}}, \mathrm{b}_{\mathrm{i}}$ and $\gamma_{\mathrm{i}}$ significantly different from zero.

Cooley and Leroy (1985) explain that we can learn from a Granger causality test, is whether a variable is exogenous or not. If variable $\mathrm{x}_{1}$ Granger-causes $\mathrm{x}_{2}$ then $\mathrm{x}_{2}$ is not exogenous; but if $\mathrm{x}_{1}$ does not Granger-cause $\mathrm{x}_{2}$ still we cannot say that $\mathrm{x}_{2}$ is exogenous.

If the F-test and its P-value are very significant, we conclude that the lagged right-hand side variable (aggregate demand and money) has significant linear predictive power (Granger-causes) for the left-hand side variable (real output).

According to the rule the reduced form evidence in table 1 shows:

- $\quad$ That money Granger-causes Y, so Y is not exogenous, since the growth rate of the money supply, strongly predicts real output. Specifically the F value from RMG to Y, is 3.855, with a significance value of .997 indicates that there is strong relationship between real output and the growth rate of the money supply. This causality between M and Y is unidirectional, and it's been found by Sims (1972) for the U.S. data.

- $\quad \mathrm{Y}$ does not cause $\mathrm{M}$ so money is exogenous (since the value of $\mathrm{F}$ from $\mathrm{Y}$ to $\mathrm{M}$ is 1.29 (.73). This however, is not a sufficient evidence to claim that money is exogenous.

- $\quad$ M Granger-causes P (see F=3.85 (.997) from M to P.

The most important finding is that money Granger-causes output. As was discussed at the introduction it is very controversial in macroeconomics whether money causes output fluctuations.

\section{Granger Causality Tests (Extended Models)}

Cyprus is an open-economy which trades the rest of the world and there is no doubt that economic performance is affected by both domestic shocks and from the rest of the world. We include the exchange rate in the three-variable model to show explicitely the impact from the rest of the world on the Cypriot economy. The four variable model includes output, Y, the price level, P, the money supply, M, and the exchange rate, XR. For the four-variable model the estimated equations are:

$\mathrm{Z}_{\mathrm{t}}=\Sigma^{\mathrm{k}}{ }_{\mathrm{i}=1} \alpha_{\mathrm{i}} \mathrm{Y}_{\mathrm{t}-\mathrm{i}}+\Sigma^{\mathrm{k}}{ }_{\mathrm{i}=1} \beta_{\mathrm{i}} \mathrm{INF}_{\mathrm{t}-\mathrm{i}}+\sum^{\mathrm{k}} \mathrm{i=1} \gamma_{\mathrm{i}} \mathrm{RMG}_{\mathrm{t}-\mathrm{i}}+\mathrm{e}_{\mathrm{t}}+\Sigma^{\mathrm{k}} \mathrm{k}=1 \gamma_{\mathrm{i}} \mathrm{XR}_{\mathrm{t}-\mathrm{i}}+\mathrm{e}_{\mathrm{t}}$

where $\mathrm{Z}=\mathrm{Y}$, INF, $\mathrm{M}$ and $\mathrm{XR}$.

In Table 2, we summarize the Granger causality results which are overall in agreement with those for the threevariable models presented in the previous section:

- $\quad$ M Granger-causes Y

- $\quad$ M Granger-causes P

- $\quad \mathrm{XR}$ Granger-causes M so XR is not exogenous.

Note that the inclusion of the XR into the model has increased the predictive power of M. 


\section{Impulse Response Functions (Irfs) Three-Variable Models}

The figures in Table1 show the responses of output $\mathrm{Y}$ and the price $\mathrm{P}$ to a positive shock in aggregate demand, a negative shock in aggregate supply and a positive shock in the growth rate of the money supply. The vertical axis in the figures denotes the level of real output or the level of price; the horizontal axis denotes time in quarters. These IRF's are cumulative, so they are the dynamic responses of the level of real output to one standard deviation of each shock in the time period of forty quarters The slope of the IRF's therefore, indicate the output growth rate and the inflation rate.

Based on economic theory we expect:

- $\quad$ A positive aggregate demand shock raises output and the price level

- $\quad$ A negative aggregate supply raises prices but reduces output

- $\quad$ A shock in the money growth raises output and prices.

If the estimated IRF's are consistent with theses relationships, our identification assumptions will prove to have been plausible. Then we can use the IRF's to investigate the experience of Cyprus is suggestive of consensus of macroeconomic view. Based on theses consensus we would also expect:

- $\quad$ A positive aggregate demand to raise $\mathrm{Y}$ and $\mathrm{P}$ only temporarily (i.e. output growth and the inflation rate remain unaffected in the long-run).

- $\quad$ A negative aggregate supply shock to also affect $\mathrm{Y}$ and the growth rate of $\mathrm{P}$ temporarily.

- A positive shock in the money growth to raise output and output growth temporarily, but the price level and the inflation rate permanently.

The figures in table 1 show that a positive aggregate demand shock moves output and prices in the same direction as predicted by the traditional AD-AS model. The increase in the level of output appears to be stable and permanent. After 10 quarters output will increase by about 4\%. The slope of the IRF of real output is getting flatter in the long-run, which means the growth rate of output increases only temporarily. Next we explain the effects of aggregate demand, aggregate supply and money supply:

\section{The effects of a positive aggregate demand}

A positive $\mathrm{AD}$ shock eventually increases the price level. There two puzzles in the price level responses in fig. $1 \mathrm{~b}$ : one is that after the shock in the inflation rate decreases for up to 5 quarters, it then increases in the price level became higher than the original level after more than 20 more quarters; the other puzzle is that in the usual AD-AS model, a positive demand shock raises the price level, and not the inflation rate, but here we see that after 5 quarters both the price level and the inflation rate keep increasing.

The effects of a negative aggregate supply

A negative AS shock moves output in the opposite directions. As predicted by theories, output decreases permanently, and it decreases faster in the first ten quarters (about 1.5\%). After 10 quarters output will decrease by about $1.7 \%$. Since the IRF is getting flatter, the growth rate of output decreases only temporarily.

The price level increases as output decreases. In the first ten quarter prices increase by about $1.8 \%$. The inflation rate first increases, then starts to decrease after 12 quarters. Price level peaks after a few quarters then slowly decreases.

The effects of a positive shock in the money growth

A positive shock in the growth rate of money increases both output and prices. The IRF of real output responses shows a permanent effect of money growth. Although output increases permanently, the IRF is getting flatter, so the 


\section{$\underline{6}$}

growth rate of output increases temporarily. Since the economy will stay at a higher steady state level of output, money growth will increase output by $1.8 \%$ after forty quarters. The IRf of the price response is positive, implying that the shocks in the money growth have permanent effects on both the price level and the inflation rate, which is supported by most theories. In table 2 the inflation rate is stable, and after 10 quarters the price level increases by $2 \%$.

Overall the IRF's are consistent with mainstream views about macro-fluctuations that all the three shocks affect output and price. So all the hypotheses of this study are supported by the analysis.

Variance Decompositions

The impulse response functions enabled us to analyze the dynamic behavior of output and prices due to unanticipated shocks given in $\mathrm{AD}, \mathrm{AS}$, and money supply. On the other hand, the variance decompositions show the relative importance of the shocks in explaining the variability of the dependent variables, Y, P, in the model.

Based on generally accepted theories, we would expect that:

- $\quad$ output variability is explained mainly by aggregate demand shocks in the short-run but in the long-run it is mainly explained by AS shocks

- $\quad$ both $\mathrm{AD}$ and $\mathrm{AS}$ shocks affect inflation variability in the short-run, but in the long-run inflation is a monetary phenomenon.

The findings of variance decompositions support the impulse response functions analysis.

\section{SUMMARY OF EMPIRICAL EVIDENCE}

\section{General Results}

At the beginning of this paper, we mentioned three questions about the sources of macro fluctuations which the VAR literature has discussed since the early 1980's. The empirical evidence from Granger causality, impulse response functions and variance decompositions provide answers to these questions.

The main conclusion of the empirical results is that all three shocks have been found to contribute to fluctuations in output and prices. We cannot single out one shock, either monetary or in productivity or in demand, as the only source of business cycles. In Cyprus shocks in money growth unambiguously raise the level of output and prices so we cannot deny the effects of nominal variables. In this study we provide evidence that in the long run monetary shocks are the main force to determine the price level. This evidence is in general consistent with the predictions of the theory. Results are comparable with the EMU-area countries. Results are also compared for similarities with other major economies such as U.S. and Japan.

\section{Policy implications}

The main policy variable in the three-variable model is the money supply, M1. The empirical evidence tells us how monetary policy can be used in the Cypriot economy, and the EMU area countries. In Cyprus, a monetary expansion would produce an output expansion, but at the cost of inflation. After a monetary expansion, at four, eight, and twelve quarters, output increases by $.6 \%, 1.2 \%$, and $1.1 \%$, the price level increases by $0 \%, .4 \%$ and $.8 \%$ respectively. But after twelve quarters, on average the price level increases three times as fast as output increases. This means in the short run and the medium monetary policy can be used to offset aggregate demand shocks; but at the cost of doing so for AS shocks would be higher since both the negative AS shock and positive monetary shock will produce an inflationary pressure. Overall results imply that macroeconomic policies in Cyprus are in accord with the EMU-area countries.

\section{FOOTNOTES}

1. See David E. Rapach (1998), Barro (1976, '77, '78), Blachard (1990), Cecchetti and Karras (1992), Shmpiro and 
$\underline{6}$

Watson (1988).

\section{REFERENCES}

1. Blanchard, O.J.: Why does money affect output? A survey. IN Handbook of monetary economics. Ed. Friedman B.M. and Hahn F.H., pp 779-835, Elsevier Science Publishers B.V., 1990.

2. Campbell, J. Y. (1991). A Variance Decomposition for Stock Returns. The Economic Journal, 101 (March 1991): 157-179.

3. Campbell, J.Y. and J. Ammer (1993). What Moves the Stock and Bond Markets? A Variance Decomposition for Long-Term Asset Returns. The Journal of Finance, vol. xlviii no.1 (March 1993):3-37.

4. Cecchetti, S. and Karras, G: Sources of output fluctuations during the interwar period: Further evidence on the causes of the great depression. NBER Working paper NO. 4049, 1992.

5. Cochrane, J.H.: Permanent and Transitory Components of GNP and Stock Prices. The Quarterly Journal of Economics, (February 1994): 241-265.

6. Gali, J. : How well does the IS-LM model fit the postwar U.S.S data? The Quarterly Journal of Economics.

7. Granger C. W. J. (1969), Investigating casual relations by Econometric Models and Cross-Spectral Methods. Econometrica Vol. 37, No.3 (July 1969).

8. J. Hamilton (1994) Time Series Analysis.

9. King, R. and Plosser, C.: Money, credit and prices in real business cycle. American Economic Review.

10. Kothari, S.P. and Jay Shanken, (1992) Stock return variation and expected dividends, a time-series and crosssectional analysis, Journal of Financial Economics, 11:117-210.

11. Lee, Bong-Soo (1992). Causal Relations Among Stock Returns, Interest Rates, Real Activity, and Inflation. The Journal of Finance, vol. xlvii, no.4 (September 1992):1591-1603.

12. Said, S. E. and Dickey, D.A. Testing for unit roots in autoregressive moving average models of unknown order, Biometrica 71: 599-608, (1985).

13. Sims, A. Money, Income, and Causality. American Economic Review, (1972) Vol.62,No.4.:540-552.

14. Shmpiro, M.D. and Watson, M.W. : Sources of business cycles fluctuations. In NBER Mcroeconomics Annual, eds O.J. Blanchard and S. Fisher, pp. 111-148, 1988.

\section{APPENDIX}

Table 1: Cyprus: Granger Causality Tests Of Three-Variable Models

\begin{tabular}{|l|cc|cc|cc|}
\hline Variables & $\mathbf{H}_{\mathbf{0}}:$ & $\boldsymbol{\alpha}=\mathbf{0}$ & $\mathbf{H}_{\mathbf{0}}:$ & $\boldsymbol{\beta}=\mathbf{0}$ & $\mathbf{H}_{\mathbf{0}}:$ & $\boldsymbol{\gamma}=\mathbf{0}$ \\
\hline Y & 3.27 & $(.993)$ & .824 & $(.44)$ & $\mathbf{3 . 8 5}$ & $(.997)$ \\
\hline INF & $(1.6)$ & $(.84)$ & .780 & $(.41)$ & 4.85 & $(.999)$ \\
\hline RMG & 1.29 & $(.773)$ & 1.23 & $(.70)$ & 21.96 & $(1.00)$ \\
\hline \multicolumn{7}{l}{ Note: } \\
\hline
\end{tabular}

Table 2: Emu-Area: Granger Causality Tests Of Three-Variable Models

\begin{tabular}{|l|ll|ll|ll|ll|}
\hline Variables & $\mathbf{H}_{\mathbf{0}}:$ & $\boldsymbol{\alpha}=\mathbf{0}$ & $\mathbf{H}_{\mathbf{0}}:$ & $\boldsymbol{\beta}=\mathbf{0}$ & $\mathbf{H}_{\mathbf{0}}:$ & $\boldsymbol{\gamma}=\mathbf{0}$ & $\mathbf{H}_{\mathbf{0}}:$ & $\boldsymbol{\delta}=\mathbf{0}$ \\
\hline Y & 2.77 & $(.98)$ & .75 & $(.39)$ & .98 & $(.55)$ & $\mathbf{4 . 3 9}$ & $(.999)$ \\
\hline INF & 1.58 & $(.83)$ & .85 & $(.46)$ & 1.20 & $(.68)$ & 4.74 & $(.999)$ \\
\hline XR & .95 & $(.51)$ & .82 & $(.44)$ & 6.75 & $(.999)$ & 1.15 & $(.657)$ \\
\hline Note & & &
\end{tabular}

Note: Bold indicates Granger-causality (predictability) from the D/P ratio or the DG rate to real stock returns.

Table 3: U.S.: Granger Causality Tests Of Three-Variable Models

\begin{tabular}{|c|c|c|c|c|c|c|}
\hline Variables & $\mathbf{H}_{0}$ : & $\alpha=0$ & $\mathbf{H}_{0}:$ & $\beta=0$ & $\mathbf{H}_{0}$ : & $y=0$ \\
\hline
\end{tabular}


6

\begin{tabular}{|l|ll|ll|ll|}
\hline \hline Y & 4.29 & $(.993)$ & .728 & $(.44)$ & $\mathbf{5 . 0 5}$ & $(\mathbf{1 . 0 0})$ \\
\hline INF & $(1.5)$ & $(.84)$ & .890 & $(.41)$ & 2.10 & $(.999)$ \\
\hline RMG & 1.39 & $(.773)$ & 1.46 & $(.70)$ & 4.16 & $(1.00)$ \\
\hline \multicolumn{2}{l|}{ Note: Bold indicates Granger-causality (predictability) } \\
\hline
\end{tabular}

Note: Bold indicates Granger-causality (predictability) from the D/P ratio or the DG rate to real stock returns.

Table 4: Japan: Granger Causality Tests Of Three-Variable Models

\begin{tabular}{|l|ll|ll|ll|ll|}
\hline Variables & $\mathbf{H}_{\mathbf{0}}:$ & $\boldsymbol{\alpha}=\mathbf{0}$ & $\mathbf{H}_{\mathbf{0}}:$ & $\boldsymbol{\beta}=\mathbf{0}$ & $\mathbf{H}_{\mathbf{0}}:$ & $\boldsymbol{\gamma}=\mathbf{0}$ & $\mathbf{H}_{\mathbf{0}}:$ & $\boldsymbol{\delta}=\mathbf{0}$ \\
\hline Y & 2.17 & $(.98)$ & .85 & $(.39)$ & .78 & $(.45)$ & $\mathbf{3 . 3 9}$ & $(\mathbf{1 . 0 0})$ \\
\hline INF & 1.08 & $(.83)$ & .75 & $(.46)$ & 1.0 & $(.78)$ & 3.14 & $(1.00)$ \\
\hline XR & .65 & $(.51)$ & .72 & $(.44)$ & 7.54 & $(1.00)$ & 1.05 & $(.557)$ \\
\hline Note: & \multicolumn{7}{|c|}{ Bold in } \\
\hline
\end{tabular}

Note: Bold indicates Granger-causality (predictability) from the Money Supply to real output.

Impulse Response Functions:

a) Cyprus 
Accumulated Responses of Aggregate Demand and Aggregate Supply to Cholesky One S.D. Innovations
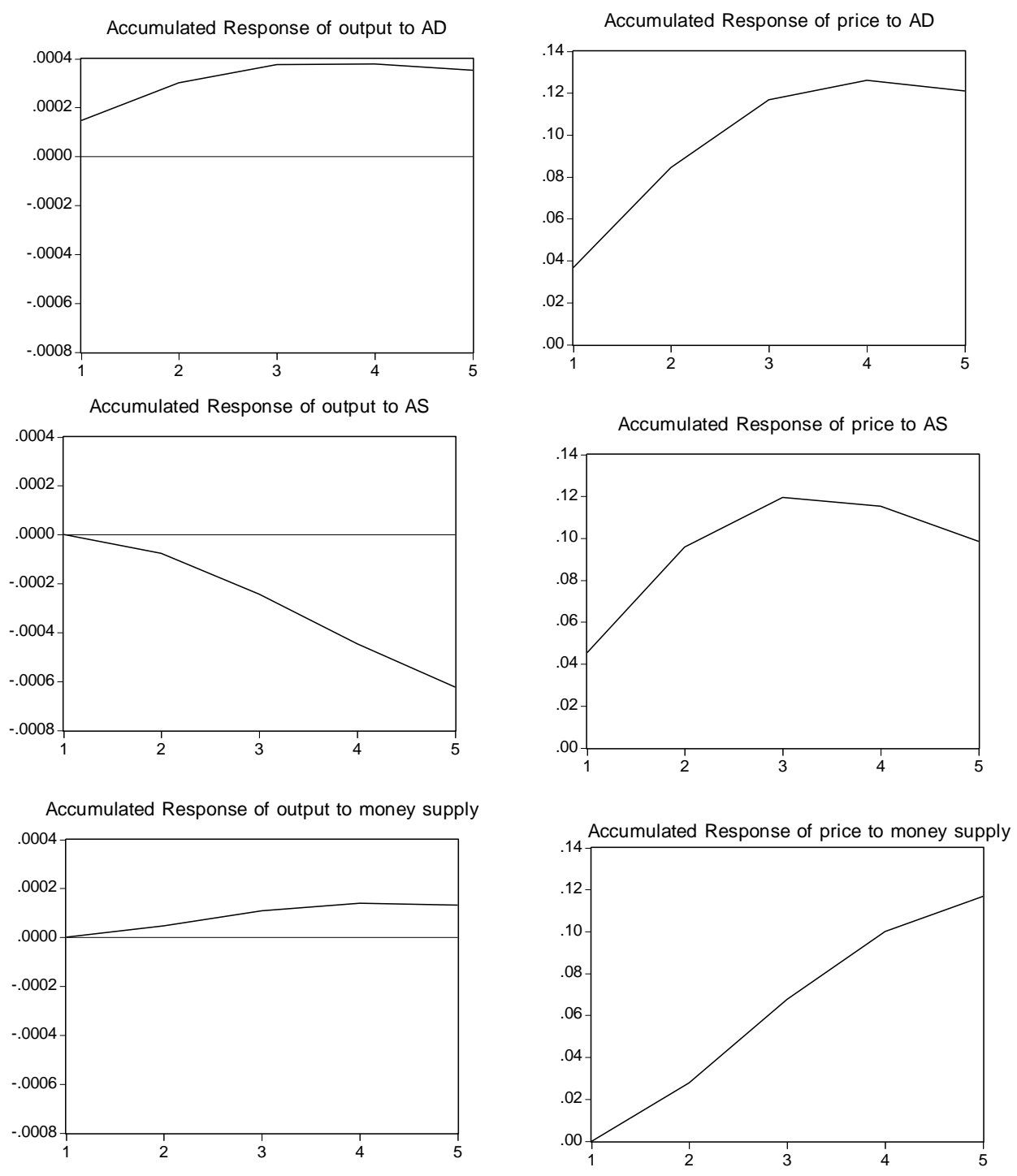

b) EMU-area 
Accumulated Response to Aggregate Demand and Aggregate Supply shocks
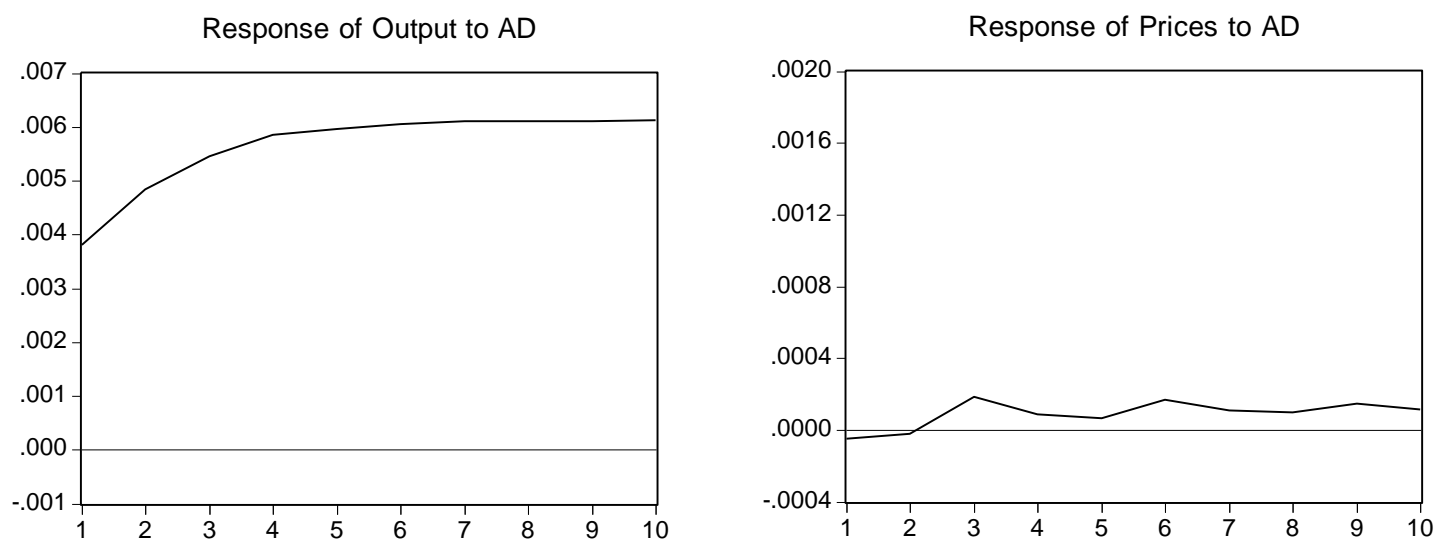

Response of Output to a negative AS
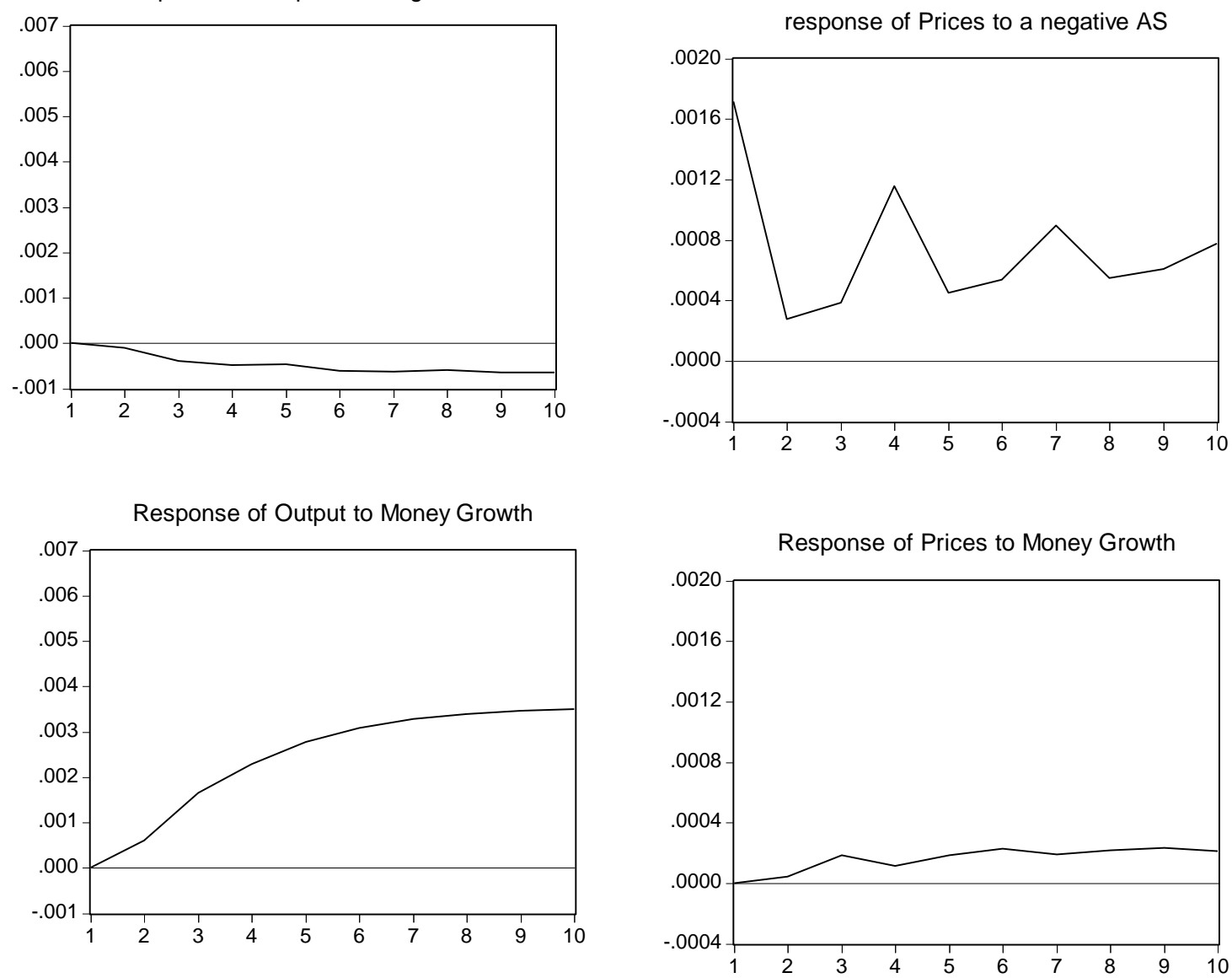

c) U.S. 
IMPULSE RESPONSE FUNCTIONS

A. UNITED STATES
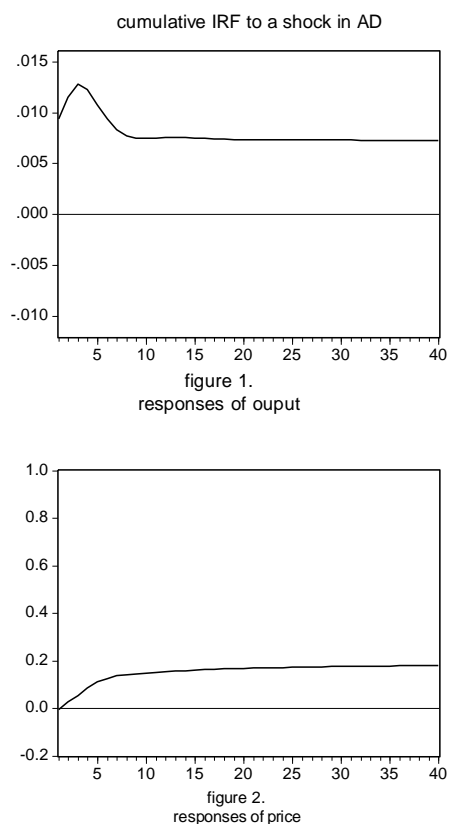

RF of $A D$
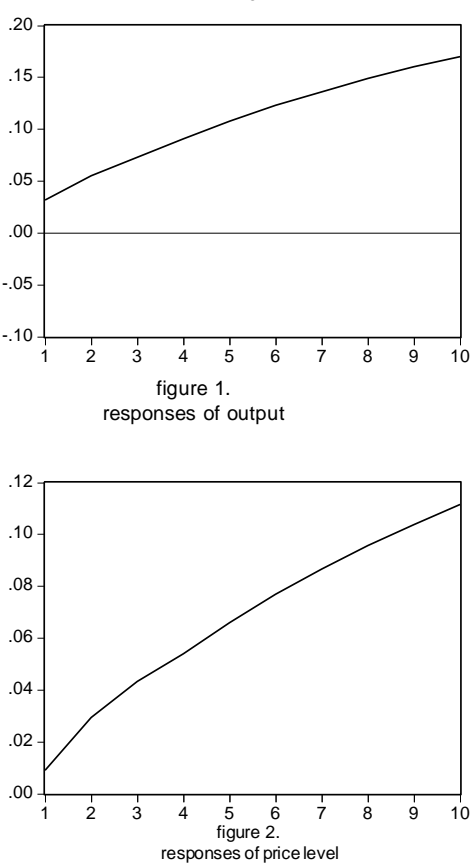

cumulative IRF to a shock in AS
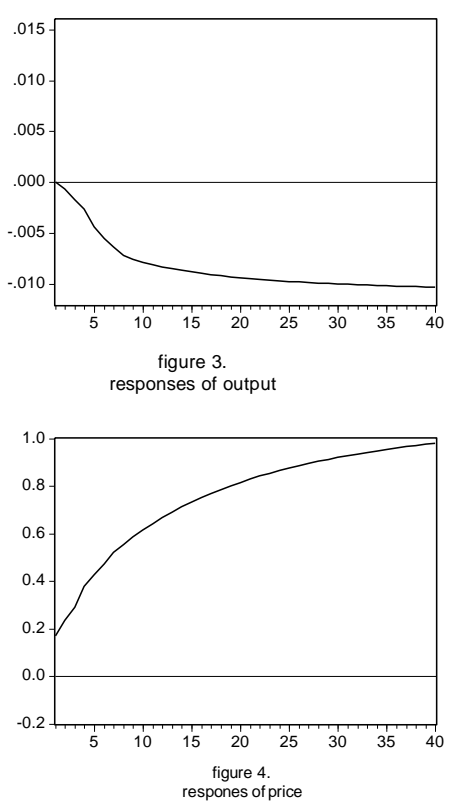

d) Japan

JAPAN

IRF of AS

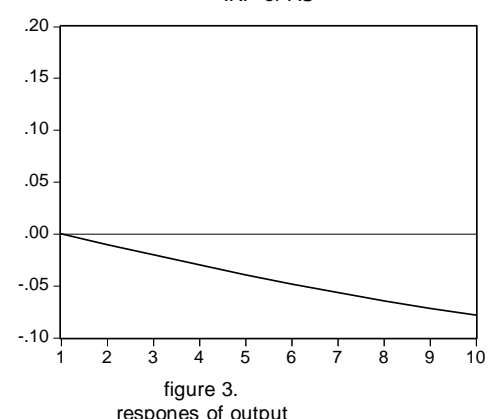

respones of output

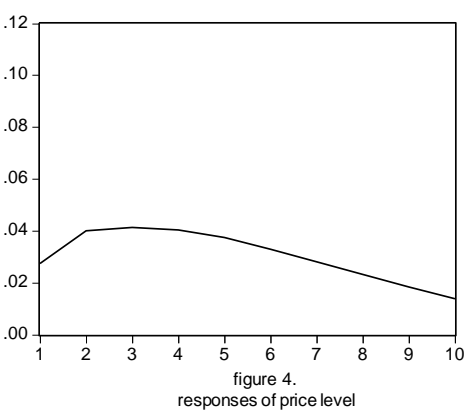

cumulative IRF to a shock in money growth
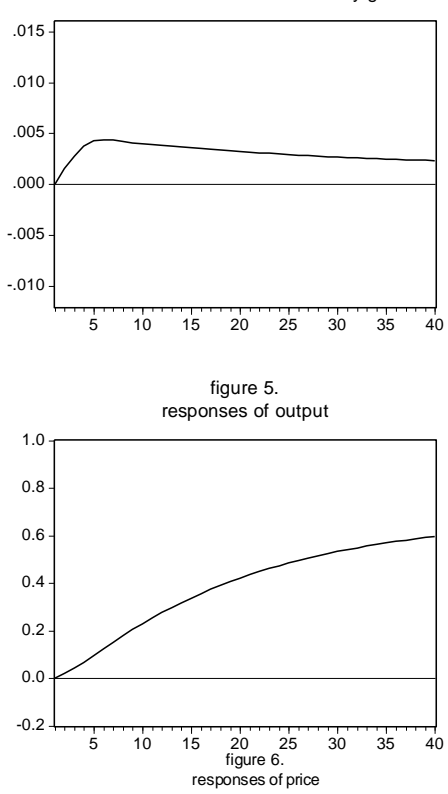

IRF of money growth
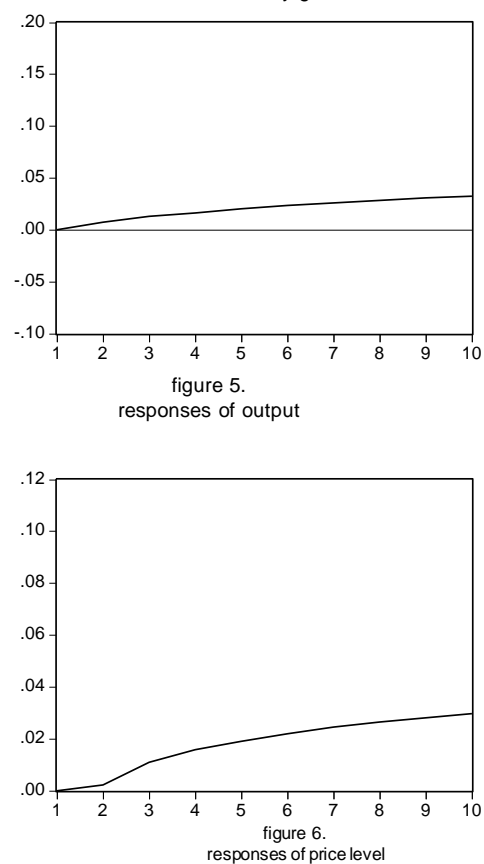

VARIANCE DECOMPOSITIONS 
a) Cyprus

\begin{tabular}{|c|c|c|c|c|}
\hline Variable Explained & Periods Ahead & & & \\
\hline & & AD & AS & $\mathbf{M}$ \\
\hline \multirow[t]{4}{*}{$\mathbf{Y}$} & 1 & 100 & 0 & 0 \\
\hline & 4 & 84.65 & 11.60 & 3.75 \\
\hline & 8 & 80.44 & 16.07 & 3.49 \\
\hline & 10 & 79.51 & 17.08 & 3.40 \\
\hline \multirow[t]{4}{*}{$\mathbf{P}$} & 1 & 9.47 & 90.53 & 0 \\
\hline & 4 & 44.44 & 49.90 & 5.56 \\
\hline & 8 & 52.70 & 41.70 & 5.60 \\
\hline & 10 & 54.00 & 40.55 & 5.45 \\
\hline
\end{tabular}

b) EMU-area

\begin{tabular}{|l|c|c|c|c|}
\hline Variable Explained & Periods Ahead & AD & AS & M \\
\hline & \multicolumn{5}{|l|}{} & AD & 0 & 10.33 \\
\hline Y & 1 & 100 & .60 & .69 \\
\hline & 4 & 89.05 & .71 & 12.19 \\
\hline \multicolumn{5}{|l|}{} \\
\hline
\end{tabular}


